\title{
SEASONALITY OF THE ACTIVITY PATTERN OF Callithrix penicillata (PRIMATES, CALLITRICHIDAE) IN THE CERRADO (SCRUB SAVANNA VEGETATION)
}

\author{
VILELA, S. L. and FARIA, D. S. de \\ Universidade de Brasília, Instituto de Biologia, Departamento de Ecologia. C.P. 04631, \\ CEP 70919-970, Brasília, DF, Brazil \\ Correspondence to: Sinara Lopes Vilela, Diretoria de Fauna e Recursos Pesqueiros, Coordenação de \\ Proteção de Espécies, Instituto Brasileiro do Meio Ambiente e dos Recursos Naturais Renováveis (IBAMA), \\ SAIN, Avenida L4 Norte s/nº, Edifício Sede, CEP 70800-200, Brasília, DF, Brazil, \\ e-mail: sinara.vilela@ibama.gov.br \\ Received September 17, 2002 - Accepted January 27, 2003 - Distributed May 31, 2004
}

(With 2 figures)

\begin{abstract}
Two wild groups of Callithrix penicillata, the Black Pincelled Marmoset, were observed from January to September 1998, in two areas, one an area of dense scrub savanna vegetation (cerrado) and the other, a semidecidual woodland (cerradão), both within the boundaries of the Ecological Reserve of IBGE (Brazilian Institute of Geography and Statistics), in an environmentally protected area, the APA (Portuguese abbreviation for "environmental protected area") Gama/Cabeça-de-Veado, Brasília, DF. The behavioral data collected during the rainy (January 15 to April 15) and dry season (June 1 to September 15) were compared. Because of the proximity to the Reserve facilities, the group from the dense scrub savanna vegetation (CD) was submitted to antropic impacts different from the group in the semidecidual woodland (CE), which was using as territory an area that had been suffering from man-made fires every two years as part of a long-term experimental project on fire impacts. The behavioral data was quantified by instantaneous cross-section ("scan sampling") every ten minutes with records of locomotion, rest, foraging for insects, use of exudate, and feeding. During the whole year, the greatest percentage of time spent by $\mathrm{CE}$ and $\mathrm{CD}$ was in foraging for insects, with $44 \%$ and $39 \%$, respectively. It was evident when comparing the data for the two seasons that, for both groups, foraging for insects was more intense during the dry season, possibly to complement the shortage of food, and locomotion increased during the rainy season. The greater the availability and distribution of fruit in the areas, the greater the locomotion of the groups to obtain these resources. None of the other behavioral patterns, including the use of exudates, presented significant differences between the two seasons. Both groups foraged more frequently during the dry season and locomoted more during the rainy one.
\end{abstract}

Key words: Callithrix penicillata, behavioural pattern, climate seasons, scrub savanna vegetation, cerrado.

\section{RESUMO}

\section{Sazonalidade do padrão de atividade de Callithrix penicillata} (Primates, Callitrichidae) no cerrado

Foram observados dois grupos selvagens de Callithrix penicillata (mico-estrela), entre janeiro e setembro de 1998, em uma área de cerrado denso e outra de cerradão, ambas localizadas na Reserva Ecológica do IBGE, que faz parte da APA do Gama/Cabeça-de-Veado, Brasília, DF. Compararamse dados de comportamento entre estação chuvosa (15/1 a 15/4) e estação seca (1/6 a 15/9). Em razão da proximidade com as instalações da reserva, o grupo do cerrado denso sofreu perturbações antrópicas. O grupo do cerradão habita uma área de 10 ha, a qual faz parte do Projeto Fogo e é queimada de dois em dois anos. Os comportamentos foram quantificados por amostragem instantânea (scan sampling), a cada dez minutos, registrando locomoção, descanso, forrageamento de insetos, uso de exsudato e 
alimentação. Durante todo o estudo, a maior parte do tempo gasto pelos dois grupos foi com forrageamento de insetos (44\%-39\%) e locomoção (24\%-22\%), sendo alimentação (8\%-7\%) e uso de exsudato ( $9 \%-9 \%)$ os padrões menos comuns. Ambos os grupos forragearam mais na estação seca e locomoveram-se mais na estação chuvosa. O uso de exsudato não apresentou diferença significativa entre as estações.

Palavras-chave: Callithrix penicillata, comportamento, estações, cerrado, padrões de atividades.

\section{INTRODUCTION}

The Black Pincelled Marmoset, Callithrix penicillata, is about $20 \mathrm{~cm}$ in height and its weight ranges from 350 to 500 grams (Stevenson \& Rylands, 1988; Faria, 1989). Individuals form groups varying from 2 to 13 (Faria, 1984a, 1986; Auricchio, 1995; Rowe, 1996). The birth pattern is twice a year coinciding with the rainy season, August to October, and from January to February, the period of more intense rains. Therefore, the occurrence of births would seem likely to occur during periods of greater environmental productivity (Faria, 1989). However, Miranda (1997) detected births for both groups of marmosets, in the same area reasearched here, at the end of the dry season.

The diet of this small primate consists of fruit, insects, nectar (Faria, 1984a, 1986; Miranda, 1997; Vilela, 1999), plant exudate (Santee \& Faria, 1985; Faria, 1984b, 1989; Fonseca \& Lacher, 1984; Lacher et al., 1981; Lacher et al., 1984; Rylands, 1984; Goldizen, 1986; Stevenson \& Rylands, 1988; Passamani, 1996; Miranda, 1997; Vilela, 1999) and new leaves and buds of leaves (Santee \& Faria, 1985).

Callithrix pencillata is distributed throughout the states of Goiás, Tocantins, Maranhão, Minas Gerais, São Paulo, and in the north of Rio de Janeiro and west of Bahia (Stevenson \& Rylands, 1988; Vivo, 1991; Auricchio, 1995; Rowe, 1996). The species is found in secondary forests, on habitat edges (Auricchio, 1995; Rowe, 1996), in gallery forests, semidecidual woodland, and scrub savanna vegetation (Fonseca \& Lacher, 1984; Faria, 1986; Stevenson \& Rylands, 1988; Miranda, 1997; Vilela, 1999). The difference in physiognomies presented by these environments is notable. Gallery forests, for example, are characterized by growing along of rivers and streams (Ribeiro \& Walter, 1998; Rezende, 1998) and by having perennial arboreal coverage ranging between $80 \%$ and $100 \%$ (Silva
Júnior et al., 1998). The semidecidual woodlands occur on inclined sandy soils, covered by a thin layer of humus, known as forest soil (Waibel, 1948). They have an arboreal coverage, that can vary from $50 \%$ to $90 \%$, characterized by the presence of species that occur both in the scrub savanna vegetation and gallery forests. Physiognomically, they woodlands are similar to a forest, but floristically they resemble scrub savanna (Ribeiro \& Walter, 1998). Therefore, the food resources they present are practically the same, although the structure of the habitat is very different.

Other behavioral and ecological aspects of Callithrix penicillata are described in the literature, i.e., territory, composition of the groups, and scentmarking. The territory and composition of the groups vary in accordance with the environment (Faria, 1984a, 1986, 1989), and scent-marking is an important behaviour in maintaining stable the relationship among individuals and defending territory (Lacher et al., 1981). Variation of the behavioral pattern depends on the area and group studied, and depends on environmental factors such as seasonality, distribution, and food abundance (Terborgh, 1983; Ferrari, 1988; Peres, 1993; Passamani, 1998).

Researches carried out on Callithrix penicillata in the gallery forest of Central Brazil describe the increase in exudate consumption during periods of food shortage during the dry season (Fonseca et al., 1980; Rizzini \& Coimbra-Filho, 1981; Lacher et al., 1984; Santee \& Faria, 1985; Faria, 1984b, 1986; Fonseca \& Lacher, 1984). This seems to be a supplementary source, since its cost exceeds that of fruit and insects (Faria, 1986). However, little is known about this species in the scrub savanna region, and further studies are necessary to know more about its behavior and adaptation to the territory used as its habitat.

The objective of the present research was to register the behavioral pattern of two groups of $C$. 
penicillata, one living in an intact area and the other in an area subject to recurrent fires, using the scrub savanna as territory. Specifically, the purpose to analyze the differences during the dry and rainy seasons registered in these groups, was which are the same as those observed by Miranda (1997), whose data indicated an increase in the foraging for insects during the dry season. He also found that fruit was an important source of food in the beginning of the rainy season, and that the use of exudate was constant during the whole year. The comparison between this work and that of Miranda (1997) should shed light on whether the behavioral pattern of this species, living in scrub savanna varies with time or not. The results may represent a characteristic of C. penicillata in this environment.

\section{MATERIAL AND METHODS}

The research was carried out in the Reserva Ecológica do Roncador, DF $\left(47^{\circ} 50^{\prime} 00^{\prime \prime}\right.$ and $48^{\circ}$ $00^{\prime} 00^{\prime \prime} \mathrm{W} ; 15^{\circ} 50^{\prime} 00^{\prime \prime}$ and $16^{\circ} 00^{\prime} 00^{\prime \prime} \mathrm{S}$ ), a party of the Brazilian Institute of Geography and Statistics (Instituto Brasileiro de Geografia e Estatística IBGE) $35 \mathrm{~km}$ distant from Brasília. The Reserve, within the Gama/Cabeça-de-Veado, an environmentally protected area, was created in 1986 and its area is $1,375.5$ ha with vegetation typical scrub savanna (cerrado) and gallery forests. The climate presents two distinct seasons, the rainy (October to April) and the dry season (May to September). Annual precipation is $1,600 \mathrm{~mm}$, and the temperature varies from 18 to $22^{\circ} \mathrm{C}$.

Two different groups of $C$. penicillata, were followed, one of them using as a habitat an area of dense that scrub savanna had not suffered from fires for more than 23 years (CD group), and the other one, the CE group, using an area of semidecidual forest which man-made fires had affected every two years, as part of long-term experimental research. These two areas do not present floristic differences, therefore the choice of the groups was based on antropic differences existing in these areas: human presence near the area which the CD group uses, and effects of fire in the area of the CE group. For each group, weekly monitoring was conducted (four times a month), using binoculars $10 \times 25$, from dawn to dusk, averaging 12 hours per day, non-stop, varying in accordance with the quantity of daylight. The data were collected in 1998 during the rainy season from January 15 to April 15, and during the dry season from June 1 to September 15 in 1998. The 24 days of observation of each group, included 147 hours of observation by direct visual contact with the $\mathrm{CD}$ group, and 140 hours with the $\mathrm{CE}$ group.

The data were collected through the instantaneous sampling method (Altman, 1974), with records taken every 10 minutes. The behavior categories observed using this method were:

- rest: animal stopped, lying, or sitting down;

- locomotion: any spacial movement (short or long) of the animal;

- food: biting, chewing or, swallowing food, excepting for exudate;

- use of exudate: scarifying and/or ingesting exudate from a tree trunk;

- foraging for insects: facial and anterior member movements, apparently as a response to any stimulus, without body locomotion, directed to a position or a specific place and followed by catching the source of the stimulus and its subsequent identification as an insect.

The time spent on main activities was organized into intervals of one hour. The percentage calculated was used in the statistics test, Chi-square, for seasonal comparison of activity pattern of the groups.

\section{RESULTS}

Since groups were not captured nor marked, the behavioral records were done according to age group. The differences are clear in each group: the juveniles, besides being of intermediary size, present gray hair; the adults are bigger have a bent posture, and hair color is a mixture of auburn and grey; the infants, besides being very small, present a white mark on the forehead. In the dry season of 1998 , a male adult of the CD group, differentiated because of its half tail, migrated to a group of six individuals, and returned only at the end of the data collection. Miranda (1997) also registered the migration of this same individual during the dry season of 1996.

There is no record of births in the CD group in this survey; however, the $\mathrm{CE}$ group bred at the end of the dry season and now comprises eight individuals (Table 1).

The registers are divided according to the hours of the day (Fig. 1). In the rainy season, best visability 
occurred during the hottest period of the day, 13:00 $\mathrm{h}$ and 14:00 h, and in the dry season it was from 10:00 h to $11: 00 \mathrm{~h}$. The percentage of the records during the rainy season $(\mathrm{N}=4,068)$ was $20 \%$ smaller than during the dry season $(\mathrm{N}=6,210)$.

During the two seasons, foraging for insects represented the pursuit occupying the greatest percentage of time spent by $\mathrm{CE}$ and $\mathrm{CD}$, accounting for $44 \%$ and $39 \%$, respectively (Table 2 ). This was the only behavioral pattern to present a significant difference between the groups $\left(X^{2}=27.41\right.$; $\mathrm{p}<$
0.001). The second most frequent behavioral pattern was locomotion; feeding was least frequent.

Comparing the frequency of the behaviour categories of each group, the fact drawing most attention is that the $\mathrm{CE}$ group foraged more during the dry season while it moved more during the rainy season $\left(X^{2}=39.61 ; \mathrm{p}<0.001\right)$ (Table 3$)$, not presenting a significant change regarding the other behavioral pattern. The $\mathrm{CD}$ group followed the same pattern $\left(X^{2}=113.49 ; \mathrm{p}<0.001\right)$, besides presenting a slight feeding increase during the dry season.

TABLE 1

Composition of the groups of Black Pincelled Marmoset and their respective territories in 1998 within the Ecological Reserve of IBGE.

\begin{tabular}{|l|c|c|c|}
\hline \multicolumn{1}{|c|}{ Groups } & $\begin{array}{c}\text { Rainy season } \\
\text { (Jan/Apr) }\end{array}$ & $\begin{array}{c}\text { Dry season } \\
\text { (Jun/Sept) }\end{array}$ & Area (ha)* \\
\hline $\begin{array}{l}\text { Dense scrub } \\
\text { savanna (CD) }\end{array}$ & 3 adults & 2 adults & 18 \\
\multirow{2}{*}{$\begin{array}{l}\text { Semideciduals } \\
\text { forest (CE) }\end{array}$} & 2 juveniles & 2 juveniles & \\
& 2 anfants & 4 juveniles & \\
\hline
\end{tabular}

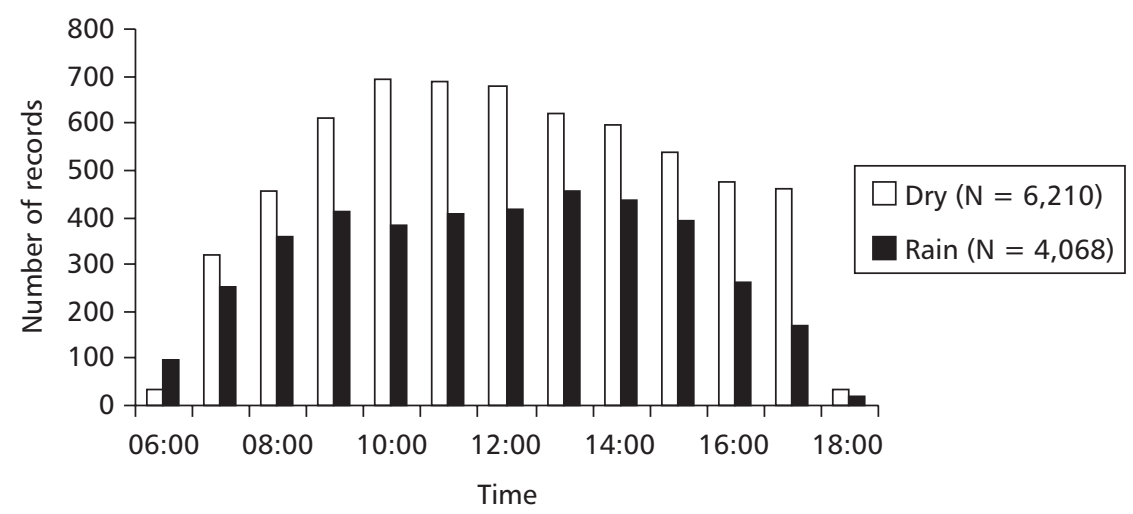

Fig. 1 - Total of scans collected for the groups of $C$. penicillata during the two seasons $(\mathrm{N}=10,278$ scans) in the Ecological Reserve of IBGE. 
TABLE 2

Percentage of time spent in behavioral patterns by the groups of Callithrix penicillata in 1998 in the Ecological Reserve of IBGE.

\begin{tabular}{|l|c|c|}
\hline \multicolumn{1}{|c|}{ Behavioral pattern } & \multicolumn{2}{c}{ Groups } \\
\hline Foraging for insects & CE $(\boldsymbol{\%})$ & CD $(\boldsymbol{\%})$ \\
Locomotion & 44 & 39 \\
\hline Rest & 22 & 24 \\
\hline Exudate-use & 19 & 19 \\
\hline Feeding & 9 & 9 \\
\hline N total $=10,278$ scans & 7 & 8 \\
\hline
\end{tabular}

TABLE 3

Behavior of the two groups of Callithrix penicillata during the two seasons in 1998 in the Ecological Reserve of IBGE.

\begin{tabular}{|l|c|c|c|c|}
\hline \multirow{2}{*}{\multicolumn{1}{c|}{ Activities }} & \multicolumn{4}{|c|}{ Groups } \\
\cline { 2 - 5 } & \multicolumn{2}{|c|}{ Semideciduals forest (CE) } & \multicolumn{2}{c|}{ Dense scrub savanna (CD) } \\
\cline { 2 - 5 } & Dry (\%) & Rainy (\%) & Dry (\%) & Rainy (\%) \\
\hline Foraging for insects & 47 & 39 & 43 & 34 \\
\hline Locomotion & 20 & 25 & 19 & 31 \\
\hline Rest & 18 & 20 & 19 & 18 \\
\hline Exudate-use & 8 & 10 & 9 & 9 \\
\hline Feeding & 7 & 6 & 9 & 6 \\
\hline
\end{tabular}

When behaviour of the two groups is compared, it is noticeably that in the dry season $\left(X^{2}=18.28\right.$; $\mathrm{p}<0.001)$ as well as in the rainy season $\left(X^{2}=23.46\right.$; $\mathrm{p}<0.001)$ the CE group foraged more than the CD group (Table 3). The locomotion pattern presented a significant difference between the $\mathrm{CE}$ and $\mathrm{CD}$ in the rainy season, when the $\mathrm{CD}$ group moved more frequently $\left(X^{2}=21.32 ; \mathrm{p}<0.001\right)$. The other behavioral pattern did not present a significant difference. Therefore, the animals foraged more for insects in the dry season and moved more in the rainy season, when fruit and other food items are more available.

The differences in percentage of time spent on the daily activities of both groups of Callithrix are listed in Fig. 2. Time spent resting was greater in the first and final hours of the day, with a small increase occurring during the middle of the day. At 6:00 $\mathrm{h}$ the $\mathrm{CE}$ group presented some movement involving foraging and feeding, contrary to the CD group, which only rested at that time. Foraging for insects and feeding increased during the day, obviously diminishing during the resting period. In short, when analzyed by seasons, the results show that both groups spent the greater part of the time in foraging for insects, and that exudate use was constant during the whole year. The data showed that no increase occurred during the dry season. Probably during this same season, the tamarins used other available food resources, resulting in a lesser effort to obtain exudate. 

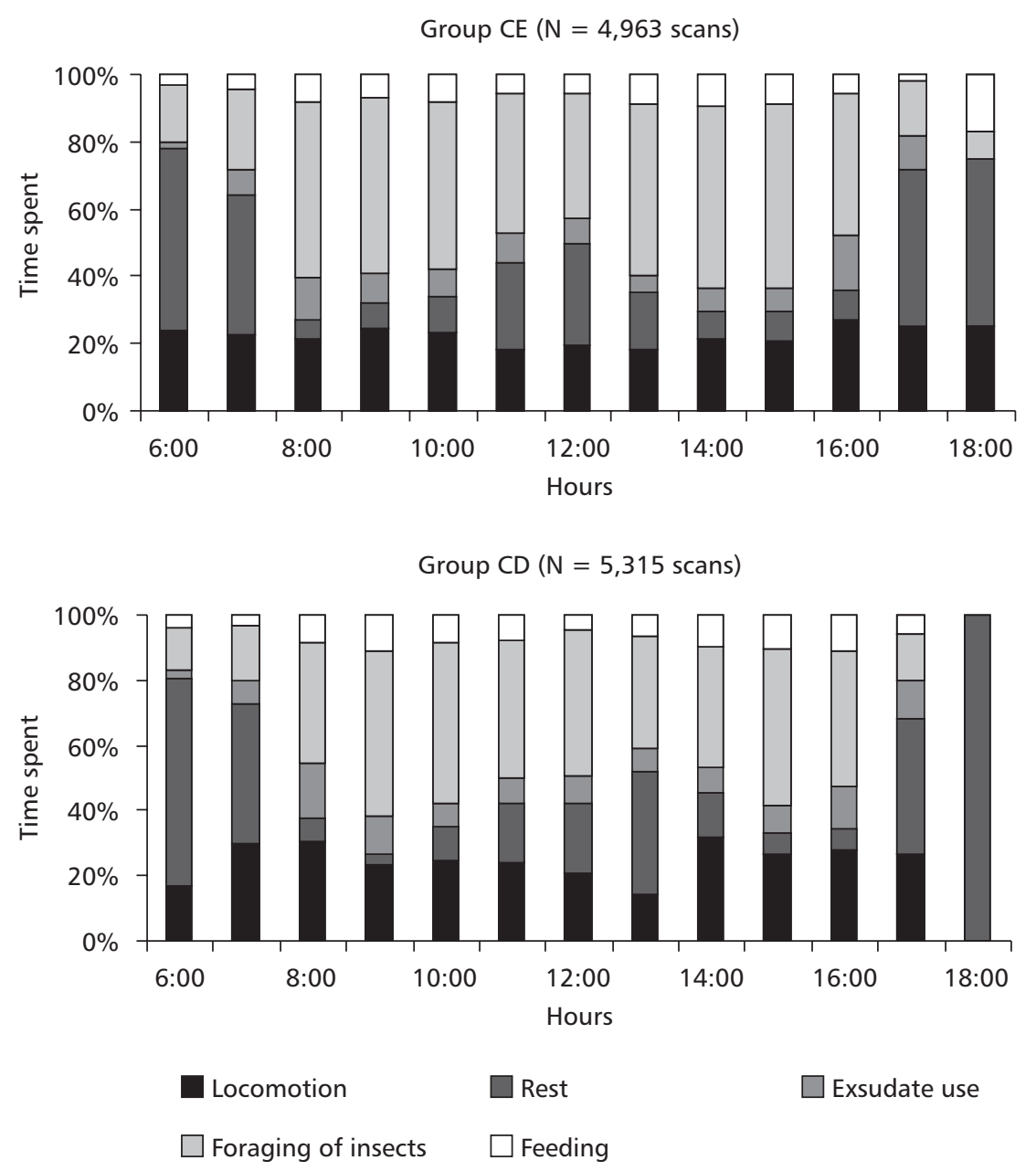

Fig. 2 - Percentage of time spent by the groups of the semidecidual forest (CE) and dense scrub savanna (CD) in main activities at intervals of an hour.

\section{DISCUSSION}

Generally, births in this species occur twice a year (Fedigan, 1992). Therefore, young of both groups that were born during the rainy season (January/February), and in the dry season in CD group, might not have survived.

There was another migration case, besides that of the male adult from the $\mathrm{CD}$ group that was also registered by Miranda (1997). An individual adult with its newborn behind was observed in the beginning of the rainy season (October) in the $\mathrm{CD}$ group, stayed with this group for only few days. It appears, therefore, that in the beginning of the rainy season, probably due to the increase in locomotion and the search for fruit, individuals from different groups are found in the environment among territories of different groups. However, more detailed research is necessary to check if this pattern really occurs.

Fonseca \& Lacher (1984), in studying the $C$. penicillata in scrub savanna confirmed that this species spends more time in exudate eating than foraging, a behavior also observed in C. jacchus (Melo et al., 1997). In this study, the groups of $C$. penicillata spent the greater part of the time $(39 \%$ and $44 \%$ ) foraging for insects, corresponding approximately to one fourth of the total activities of the group. In contrast, Miranda (1997), in studying the 
same group of $C$. penicillata described in this research, detected that the more frequent behavioral pattern was locomotion ( $45 \%$ and $34 \%$ ). This difference in behavioral pattern can be associated to variations and modifications that occur in the territories: and the increase or decrease of insect availability and other resources of a seasonal nature. Depending on these modifications, the animals move in pursuit of available items to eat.

Greater visual contact with the groups was obtainded during the rainy season in the hottest period of the day (13:00 h to $14: 00 \mathrm{~h})$, when individuals are resting in the scrub savanna and, consequently, are more visible since the trees are more widely scattered. In gallery forests, the opposite occurs because in the hotter period of the day, individuals search for more dense woods to protect themselves from both sun and predators and therefore, are more difficult to site (Faria, 1989). Better visibility during the dry season, at around 10:00 $\mathrm{h}$ and 11:00 $\mathrm{h} \mathrm{am}$, can be explained by an increase in foraging for insects, which this species carries out in the soil, making visibility and observation easier.

During the dry season, the greater visual contact with the groups coincides with an increase in activities due to food shortage, or the less coverage of the vegetation, since many deciduous species shed their leaves at this time of year.

Despite the significant difference between the groups, both foraged more during the dry season, presenting the same pattern observed by Miranda (1997), and explainable by the increase in insect occurrence and well as that of other animals, and decreased fruit suplly.

Both groups of $C$. penicillata move more during the rainy season, a fact that was also observed by Ferrari (1988) in studying groups of $C$. flaviceps. With the onset of the rains, fruit is more frequent and its distribution is scattered, so the marmoset groups range further within their territories in its searching. As the territory of the CD group is bigger, its movement is correspondingly bigger than that of the CE group.

The group of the semidecidual forest (cerradão) (CE) showed a greater percentage engaged in foraging for insects when compared to the group of dense scrub savanna vegetation (CD). This difference is significant, and probably due to the smaller area of semidecidual forest and to the biennial fires to which the area is submitted and, consequently, the reduced availability of fruit.

Regarding the use of exudate, there were no differences in inter- and intra-groups between seasons, a result contradicting those in the literature (Rylands, 1984; Faria, 1986; Stevenson \& Rylands, 1988) describing more intense use of exudate during the dry season. Considering that exudate seems to be a supplementary provision, it can be concluded that increase or decrease in its use depends on available food resources. Particularly, since the cost of its acquisition is high, it therefore tends to be used only when necessary.

Differences in behavioral pattern between the two groups were found in the final daylight hour (6:00 h). While the CE group continued foraging and feeding the $\mathrm{CD}$ group rested. The explanation is that the territory of the $\mathrm{CD}$ group is practically twice as big as the territory of the CE group (Miranda, 1997) and, consequently, food availability is greater and appetites more quickly satiated.

The foraging pattern for insects and food (fruit, etc.) was more intense during the morning and afternoon, and diminished in the reamaining hours, when the rest occurred. This behavior is also observed in other species of the genre Callithrix (Ferrari, 1988; Passamani, 1998).

Therefore, one can conclude that the greater the fruit availability and distribution in the areas, the greater the locomotion of the groups. As the supply increases during the rainy season, the groups tend to move more. The more intense foraging for insects during the dry season is due to their increased occurrence, coupled to the shortage of food, which is supplemented by the use of exudate. Exudate use was constant during the whole year, and did not rise during the dry season. If we consider that obtaining exudate is costly, maybe its use only intensifies when insect and fruit availability is restricted.

However, future research must be directed to further examples of the same vegetational types, since there are few studies of the species in scrub savanna vegetation, nor of migratory pattern and settling in areas with intermediate levels of food richness.

Acknowledgments - Thanks are owed to Iracema Gonzales, Director of the Reserva Ecológica do IBGE, for authorizing the work, and to CAPES for financial support; to Guilherme Miranda for his help in locating the groups; to Raimundo P. B. Henriques for his valuable suggestions; and to Saulo M. A. Andrade for help with translations. 


\section{REFERENCES}

ALTMANN, J., 1974, Observational study of behaviour: sampling methods. Behav. 49: 226-267.

AURICCHIO, P., 1995, Primatas do Brasil. Terra Brasilis Editora Ltda., São Paulo, Brasil.

FARIA, D. S. de, 1984a, Aspectos Gerais do Comportamento de Callithrix jacchus penicillata em mata ciliar do cerrado. In: M. T. Mello (ed.), A Primatologia no Brasil. Sociedade Brasileira de Primatologia, Brasília, DF, pp. 55-65.

FARIA, D. S. de, 1984b, Uso de árvores gomíferas do cerrado por Callithrix penicillata jacchus, In: M. T. Mello (ed.), A Primatologia no Brasil. Sociedade Brasileira de Primatologia, Brasília, DF, pp. 83-96.

FARIA, D. S. de, 1986, O estudo de campo do "mico estrela", Callithrix penicillata do Planalto Central Brasileiro. In: C. Ades (org.), Etologia de Animais e de Homens. EDICON/ EDUSP, São Paulo, pp. 109-121.

FARIA, D. S. de, 1989, O grupo social em Callithrix penicillata, o Mico-Estrela do Planalto Central Brasileiro: estudo realizado na floresta de galeria do córrego Capetinga, Brasília, DF. Tese de Doutorado, Universidade de São Paulo.

FEDIGAN, L. M., 1992, Primate Paradigms, Sex Roles and Social Bonds. University of Chicago Press, Chicago.

FERRARI, S. F., 1988, The behaviour and ecology of the BuffyHeaded marmoset, Callithrix flaviceps. Tese de Doutorado, Universidade de Londres.

FONSECA, G A. B. \& LACHER Jr., T. E., 1984, Exudate-feeding by Callithrix jacchus penicillata in semideciduals woodland (cerradão) in central Brazil. Primates, 25: 441-450.

FONSECA, G. A. B., LACHER, T. Jr., ALVES, C. Jr. \& MAGALHÃES-CASTRO, B., 1980, Some ecological aspects of free-living black-tufted-ear marmoset (Callithrix jacchus penicillata). Antropol. Contemp., 3: 197 (Abstract).

GOLDIZEN, A. W., 1986, Tamarins and Marmosets: Communal Care of Offspring. In: B. B. Smuts, D. L. Cheney, R. M. Seyfarth, R. W. Wrangham \& T. T. Struhsaker (eds.), Primate Societies. The University of Chicago, pp. 34-43.

LACHER, T. Jr., FONSECA, G. A. B., ALVES, C. Jr. \& MAGALHÃES-CASTRO, B., 1981, Exudate-eating, scentmarking and territoriality in wild populations of marmosets. Anim. Behav., 29: 306-307.

LACHER, T. Jr., FONSECA, G. A. B., ALVES, C. Jr. \& MAGALHÃES-CASTRO, B., 1984, Parasitism of trees by marmosets in a Central Brazilian Gallery Forest. Biotrópica, 16(3): 202-209.

MELO, L. C. O., MONTEIRO DA CRUZ, M. A. O. \& SILVA, V. L., 1997, Distribuição horária da marcação-de-cheiro em Callithrix jacchus na estação do Tapacurá, PE, Brasil, 34. In: Vlll Congresso Brasileiro de Primatologia, VReunião Latino-Americana de Primatologia. João Pessoa, Paraíba.

MIRANDA, G. H. B. de., 1997, Aspectos da Ecologia e Comportamento do Mico-Estrela (Callithrix penicillata) no Cerradão e Cerrado Denso da Área de Proteção Ambiental (APA) do Gama e Cabeça-de-Veado, DF. Dissertação de Mestrado, Universidade de Brasília.
PASSAMANI, M., 1996, Uso de árvores gomíferas por Callithrix penicillata no Parque Nacional da Serra do Cipó, MG. Bol. Museu Biol. Mello Leitão, 4: 25-31.

PASSAMANI, M., 1998, Activity Budget of Geoffroy's Marmoset (Callithrix geoffroyi) in an Atlantic Forest in Southeastern Brazil. Am. J. Primat., 46: 333-340.

PERES, C. A., 1993, Diet and feeding ecology of saddle-back (Saguinus fuscicollis) and moustached (S. mystax) tamarins in an Amazonian terra firme forest. J. Zool., 230: 567-592.

REZENDE, A. V., 1998, Importância das matas de galeria: manutenção e recuperação. In: J. F. Ribeiro (ed.), Cerrado: matas de galeria. Embrapa, CPAC, pp. 1-15.

RIBEIRO, J. F. \& WALTER, B. M. T., 1998, Fitofisionomias do Bioma Cerrado. In: S. M. Sano \& S. P. de Almeida (eds.), Cerrado: ambiente e flora. Embrapa, CPAC, pp. 89-152.

RIZZINI, C. T. \& COIMBRA-FILHO, A. F., 1981, Lesões produzidas pelo sagui, Callithrix penicillata (Callitrichidae, Primates) em árvores do cerrado. Rev. Brasil. Biol., 41: 579583.

ROWE, N., 1996, The pictorial guide to living primates. Pogonias Press, East Hampton, New York.

RYLANDS, A. B., 1984, Exudate-eating and tree-gouging by marmosets (Callitrichidae, Primates), Tropical Rain Forest. The Leeds Symposium, pp. 155-168.

SANTEE, D. P. \& FARIA, D. S. de., 1985, Padrões de comportamento utilizados pelos saguis (Callithrix jacchus penicillata) na retirada de exsudato. Psicologia, 11(1): 65-74.

SILVA-JÚNIOR, M. C. da, FELFILI, J. M., NOGUEIRA, P. H. \& REZENDE, A. V., 1998, Análise florística das matas de galeria no Distrito Federal. In: J. F. Ribeiro (ed.), Cerrado: matas de galeria. Embrapa, CPAC, pp. 53-82.

STEVENSON, M. F. \& RYLANDS, A. B., 1988, The marmosets, genus Callithrix. In: R. A. Mittermeier, A. B. Rylands, A. Coimbra-Filho \& G. A. B. Fonseca (eds.), Ecology and behavior of neotropical primates, vol. 2. World Wildlife Fund, Washington, D.C, pp. 131-222.

TERBORGH, J., 1983, Five New World Primates. A study in comparative ecology. Princeton University Press, New Jersey.

VILELA, S. L., 1999, Aspectos ecológicos e comportamentais de dois grupos de Callithrix penicillata (Primates, Callitrichidae) em fisionomia de cerrado denso e cerradão e comparação entre estação seca e chuvosa, incluindo dados fenológicos, Brasília, DF. Dissertação de Mestrado, Universidade de Brasília.

VIVO, M., 1991, Taxonomia de Callithrix erxleben, 1777 (Callitrichidae, Primates). Fundação Biodiversitas, Belo Horizonte.

WAIBEL, L., 1948, A vegetação e o uso da terra no Planalto Central. Rev. Bras. Geog., 38: 529-554. 